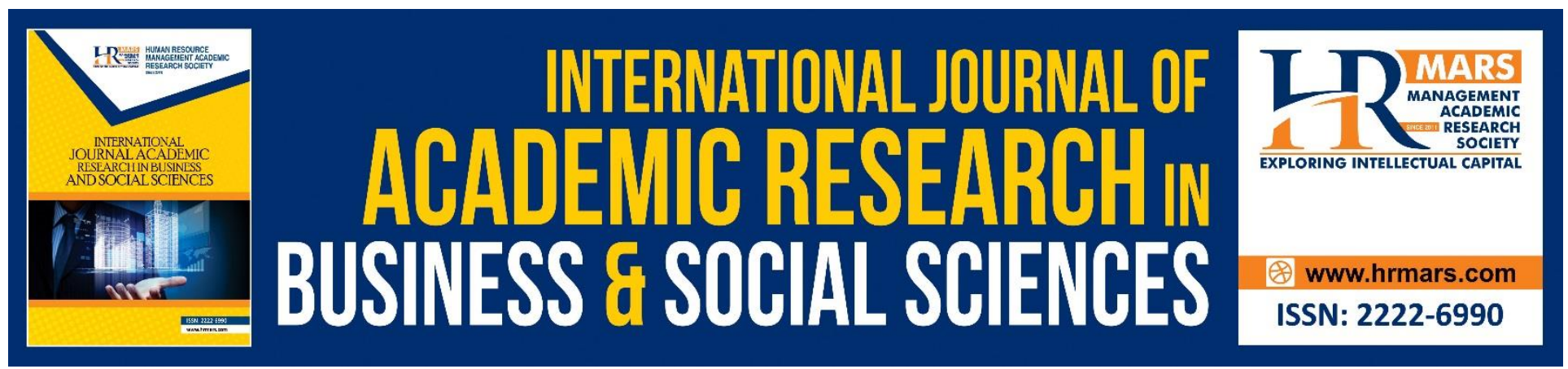

\title{
Utilizing Music and Songs to Promote Student Engagement in ESL Classrooms
}

Daler Bokiev, Umed Bokiev, Dalia Aralas, Liliati Ismail, Moomala Othman

To Link this Article: http://dx.doi.org/10.6007/IJARBSS/v8-i12/5015

DOI: $10.6007 /$ IJARBSS/v8-i12/5015

Received: 12 Oct 2018, Revised: 29 Dec 2018, Accepted: 13 Dec 2018

Published Online: 19 Dec 2018

In-Text Citation: (Bokiev, Bokiev, Aralas, Ismail, \& Othman, 2018)

To Cite this Article: Bokiev, D., Bokiev, U., Aralas, D., Ismail, L., \& Othman, M. (2018). Utilizing Music and Songs to Promote Student Engagement in ESL Classrooms. International Journal of Academic Research in Business and Social Sciences, 8(12), 314-332.

Copyright: (C) 2018 The Author(s)

Published by Human Resource Management Academic Research Society (www.hrmars.com)

This article is published under the Creative Commons Attribution (CC BY 4.0) license. Anyone may reproduce, distribute, translate and create derivative works of this article (for both commercial and non-commercial purposes), subject to full attribution to the original publication and authors. The full terms of this license may be seen

at: $\underline{\text { http://creativecommons.org/licences/by/4.0/legalcode }}$

Vol. 8, No. 12, 2018, Pg. 314 - 332

http://hrmars.com/index.php/pages/detail/IJARBSS

JOURNAL HOMEPAGE

Full Terms \& Conditions of access and use can be found at http://hrmars.com/index.php/pages/detail/publication-ethics 


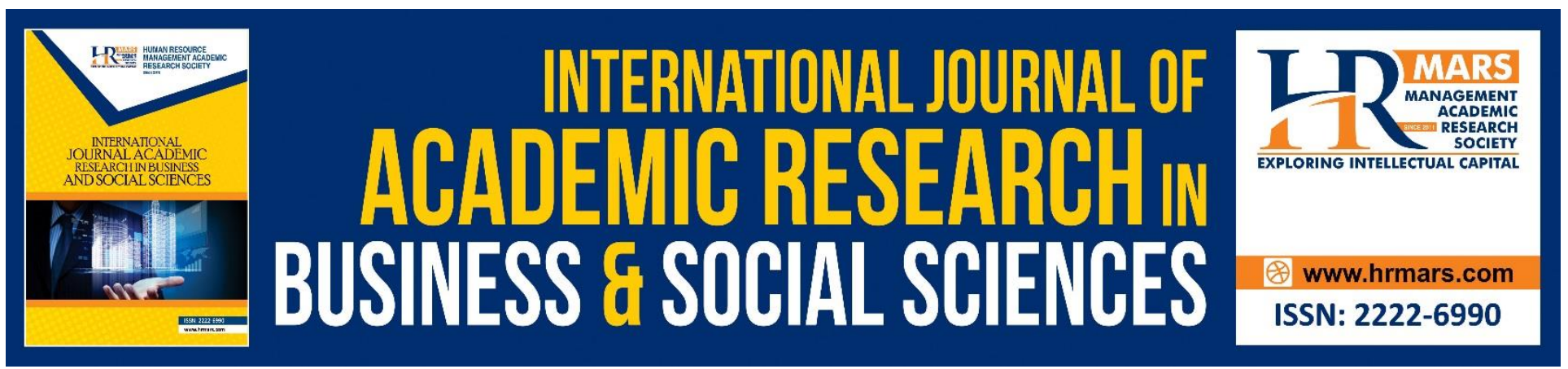

\title{
Utilizing Music and Songs to Promote Student Engagement in ESL Classrooms
}

\section{Daler Bokiev, Umed Bokiev, Dalia Aralas, Liliati Ismail, Moomala Othman}

Faculty of Educational Studies, Universiti Putra Malaysia, 43400 UPM Serdang, Selangor Darul Ehsan, Malaysia

\begin{abstract}
One of the main challenges English language teachers face in their daily classes is to find creative ways of sustaining their students' interest in language learning, which can often be perceived as dull and tedious. Music and songs, which have a universal appeal and ubiquitous presence in most people's daily lives, have all the prerequisites to become an effective teaching resource in this respect. However, this useful resource appears to be underutilized by English language teachers, which is attributable to the lack of understanding of its theoretical rationale and benefits. The present paper aims to analyze the role and potential of music and songs in English language teaching in the light of current research and literature. Research findings suggest that the effective use of music and songs in language teaching has the potential to address multiple intelligences, reduce anxiety, increase motivation, facilitate memory retention and establish an affectively conducive learning environment. Moreover, music and songs can be utilized to enhance the learning of almost every aspect of the target language, to develop cultural awareness and to foster students' creativity. Apart from discussing theoretical arguments and empirical evidence in support of using music and songs in language instruction, the paper provides practical suggestions for integrating music activities into ESL classrooms. It is hoped that a larger number of ESL teachers will deem music and songs a valuable educational tool which they can use to engage their students both affectively and cognitively and to promote effective and enjoyable language teaching and learning.
\end{abstract}

Keywords: Music, Songs, English Language Teaching, Student Engagement, Creativity

\section{Introduction}

Music is present almost everywhere and is an integral part of our everyday lives. We listen to music when we are happy and when we are upset, while exercising, studying, working, resting, running, driving and flying. We hear it on the radio and television, in cinemas, at sports and cultural events, at weddings, in restaurants and shopping malls, and when we are placed on hold during a telephone 
call. Music has been efficiently exploited in the film and advertising industry because of its capacity to evoke strong emotions and trigger memory, apart from being enjoyable.

Music is not only pleasant to hear (hence the expression music to one's ears), but also beneficial to health and well-being, which explains why it is frequently used as a therapeutic tool. As studies have shown, listening to certain kinds of music can improve mood, decrease depression, reduce stress, relieve pain (e.g. for surgery patients), stabilize heart rate, blood pressure and breathing rate, help consume less food, boost the immune system, help treat insomnia, increase exercise endurance and improve running motivation and performance (Drazen \& Woods, 2003; Harmat, Takács, \& Bodizs, 2008; Karageorghis et al., 2009; Trappe, 2009; Cervellin \& Lippi, 2011; Snyder, Snaterse, \& Donelan, 2012; Chanda \& Levitin, 2013; Schäfer, Sedlmeier, Städtler, \& Huron, 2013). Moreover, a recent study found that listening to "happy music" facilitates divergent thinking, which is a key element of creativity (Ritter \& Ferguson, 2017). Hence, music is not only a form of art meant for entertainment, but also a kind of healing art or a medicine for the soul and body, in a manner of speaking. At the same time, music can be used for educational purposes, especially in language teaching.

One of the main challenges English language teachers face in their daily classes is to find creative ways of sustaining their students' interest in language learning, which can often be perceived as dull and tedious. Music and songs, which have a universal appeal and ubiquitous presence in most people's daily lives, have all the prerequisites to become an effective teaching resource in this respect. However, this useful resource appears to be underutilized by English language teachers, which is largely attributable to the lack of understanding of its theoretical rationale and how to exploit it in ESL classrooms as well as the scarcity of publications on this subject (González, 2007; Salcedo, 2010; Engh, 2013). The present paper aims to analyze the role and potential of music and songs in English language teaching in the light of current research and literature. After discussing theoretical arguments and empirical evidence in support of using music and songs in language instruction, the paper will provide some practical suggestions for integrating music activities into English language teaching. It is obvious that the present paper cannot claim to provide an exhaustive account of all the possible ways music can be used in ESL classrooms, which depend on each individual teacher's resourcefulness and creativity.

\section{Rationale for Using Music and Songs in ELT}

In this section, we will discuss some of the main reasons for using music and songs in language teaching that are supported by theory and research.

\section{Music and Language}

The Theory of Multiple Intelligences, developed by Gardner (1983) on the basis of research in several disciplines (including psychology, brain science, genetics and anthropology), asserts that human beings possess a set of relatively independent intellectual capacities that they draw on individually and corporately, rather than a single intelligence measured by traditional IQ tests. These multiple intelligences include linguistic intelligence (analyzing and creating oral and written language); logicalmathematical intelligence (making calculations and solving abstract problems); musical intelligence 
(discerning and expressing different sound patterns); spatial intelligence (perceiving the visual-spatial world and forming mental imagery); bodily-kinesthetic intelligence (using physical skills to produce things and solve problems); interpersonal intelligence (understanding other people's moods and interacting with them); intrapersonal intelligence (knowing oneself and directing one's actions accordingly) and naturalistic intelligence (identifying living beings and features of the natural world) (Davis, Christodoulou, Seider \& Gardner, 2011). According to Gardner (2013), these intelligences are combined in a different fashion in each individual and "strength (or weakness) in one intelligence does not predict strength (or weakness) in any other intelligences". He further notes that only two intelligences - linguistic and logical-mathematical - have been valued and tested for in modern schools (Davis, Christodoulou, Seider \& Gardner, 2011).

One of the main educational implications of this theory is that ideas, concepts and skills should be taught in different ways so that as many of the intelligences as possible can be exploited to develop a particular intelligence. Even if language teachers may not be interested in developing musical intelligence per se, they can still tap their students' musical intelligence and interest so as to help them achieve mastery in the target language. Irrespective of whether or not a teacher and students have received musical training, music and songs can be easily integrated into classroom activities and thus function as a teaching tool in a way similar to audiovisual material or computer software that are employed in language education. Classroom activities involving music and songs can be used in a variety of ways to improve the learner's interpersonal, intrapersonal and bodily-kinesthetic intelligences in addition to musical and linguistic intelligences (Failoni, 1993; Campbell, Campbell \& Dickinson, 1996; Abbott, 2002).

The importance of utilizing music and songs in language teaching can be further illustrated by the close relationship between music and language. According to Gardner (2011), musical intelligence, which is the earliest to emerge of all, develops in parallel to linguistic intelligence. Moreover, both musical and linguistic competences rely on the oral-auditory system and are not dependent upon physical objects (Gardner, 2011). It is notable that music and language share some intrinsic features, such as volume, pitch, rhythm, tone, stress and pauses (Mora, 2000). What is interesting about the development of both music and language is that in both cases receptive skills come before productive skills (Sloboda, 1989). Furthermore, latest brain imaging studies indicate that music and language are closely interlinked at the neural level and that speech and music share a large number of common functional aspects (Besson, Schön, Moreno, Santos, \& Magne, 2007; Jäncke, 2012; Putkinen, Tervaniemi, Saarikivi, de Vent, \& Huotilainen, 2014), which stands in striking contrast to the popular views on the brain processing that equate music with the right hemisphere and language with the left hemisphere. Studies also suggest that that "speech functions can benefit from music functions and vice versa" (Jäncke, 2012, p. 1), which is in line with a recent review of studies by Brandt, Slevc and Gebrian (2012) concluding that "musical hearing and ability is essential to [early] language acquisition" (p. 1). As suggested by the findings of the study by Schön et al. (2008), which compared the efficiency of learning words from an artificial language in spoken and sung sequences, music can also facilitate learning a new language, particularly in the initial stages of learning when segmenting words. Thus, given the ability of music to trigger multiple intelligences, the commonalities between 
INTERNATIONAL JOURNAL OF ACADEMIC RESEARCH IN BUSINESS AND SOCIAL SCIENCES

Vol. 8, No. 12, Dec, 2018, E-ISSN: 2222-6990 @ 2018 HRMARS

music and language as well as the facilitative role of music in language acquisition, it is advisable to include music activities in the English language teaching, especially in beginning classes.

\section{Music and Affect}

Affect can be broadly defined as "aspects of emotion, feeling, mood or attitude which condition behaviour" (Arnold \& Brown, 1999, p. 1). Since the 1970s it has been known that positive affective variables impact cognitive functions and are indispensable in language acquisition (Gardner \& Lambert, 1972). Stevick (1980) comments on the importance of affect in language classrooms as follows: "Success [in language learning] depends less on materials, techniques and linguistic analyses and more on what goes on inside and between the people in the classroom" (p. 4). Krashen's (1982) Monitor Model and in particular the Affective Filter Hypothesis draw special attention to learners' emotional states in second language acquisition. Based on research findings in the area of SLA, Krashen (1982) maintains that a number of affective variables, such as motivation, self-confidence and anxiety play a decisive role in second language acquisition. He asserts it is highly probable that strong motivation, high self-confidence and a low level of anxiety in learners will lead to success in second language acquisition. Conversely, if learners suffer from lowered self-esteem and feel extremely anxious, their affective filter will rise and the processing of the language input will be inhibited, which will end in the failure of the language acquisition (Krashen, 1982).

The major implication of the Affective Filter Hypothesis is that a prerequisite for successful second language acquisition is a low-anxiety, non-threatening classroom atmosphere that arouses positive emotions in learners. This is where music and songs can play a facilitative role. It is very likely that learners will feel lower levels of anxiety and inhibition if songs are used in teaching new concepts and vocabulary (Metaxa, 2013). While listening to music can help learners feel relaxed and become creative (Mora, 2000), group singing can "lower the walls between people, decrease competitive instincts and build cooperation" (Jackson \& Joyce, 2003, p. 7). Singing songs can also boost learners' self-confidence as it enables them to master certain English words and expressions contained in the lyrics, which they will be able to use in speaking later on. It is a pleasant experience for learners to simply listen to music or to sing in chorus (Medina, 2002), which is often absent in language classrooms. As Richard (1969) points out: "Pleasure for its own sake is an important part of language learning, a fact which is often overlooked by the teacher in his quest for teaching points, or by the course designer focusing on presentation or repetition" (p. 24). Furthermore, the use of music in the classroom can benefit teachers as well and make language teaching less stressful. As stated by Brown (1998), music "can help make teaching more enjoyable by bringing us closer to our students and, more importantly, closer to ourselves" (p. 68).

Apart from their soothing effect, songs can be beneficial to language teaching by improving learners' motivation, which is fundamental to a successful learning process. As pointed out by Peacock (1997), language learners' motivation can be increased significantly through the employment of authentic materials. Since songs are linked to emotions and contain lyrics that are authentic and meaningful to the learners, they are likely to spark students' intrinsic motivation, which is generally considered superior to extrinsic motivation in terms of learner outcomes (Crookes \& Schmidt, 1991; Deci, 1995). 
The use of songs can help learners receive exposure to authentic language input. Yet, songs can also give teachers the opportunity to engage learners in real-life tasks by asking them do something that they would do in their daily life. This is especially applicable to teenagers, who devote a great amount of their free time to listening to songs.

The positive effect of music and songs on the emotional state of young and adult language learners has been confirmed by several studies (Green, 1993; Arévalo, 2010; Ludke, 2010; Setia et al., 2012; Kara \& Aksel, 2013; Džanić \& Pejić, 2016). Notably, the study by Setia et al. (2012) investigated the effectiveness of songs in creating positive attitude and motivation in primary school ESL learners in Malaysia. The results indicated that "the use of song not only helps the understanding, it also stimulates and increases the students' interest to learn, enjoy and engage in the learning process" (p. 270). The results also suggest that songs have a positive impact on the learners' self-confidence and academic success by providing a more relaxed and propitious learning environment. A similar study by Džanić and Pejić (2016) examining the influence of visual and aural representation of language through songs on language acquisition of young EFL learners in Bosnia and Herzegovina showed that songs can make language learning more gratifying and productive for different types of learners in both aural and visual settings. The researchers further stated that "songs aid motivation and help learners develop a love for language learning. Students motivated in this way are imaginative, creative, and eager to learn and succeed" (Džanić \& Pejić, 2016, p. 51). Finally, the study by Kara and Aksel (2013), which investigated the effectiveness of music in teaching grammar to university students in Turkey, found that music activities served both educational and psychological needs of the students, creating an enjoyable atmosphere and motivating them to learn the target language.

\section{Music and Memory}

As stated by Thornbury (2006), "There is no learning without memory, and language learning in particular, with the enormous load of vocabulary that it requires, is largely a memory task" (p. 129). Successful second language learning implies that learners can memorize the studied material and call on it whenever they need it while using the language. Several authors point out that music and songs can facilitate the long-term retention of the words, phrases and formulaic sequences that learners need to memorize (Mora, 2000; Abbott, 2002; Lake, 2002; Lowe, 2007; Kerekes, 2015). 
Contemporary memory models differentiate between three components of memory: (1) sensory memory, which captures the information in the environment detected by the sense organs and lets it go quickly if no attention is paid; (2) working memory, which has limited capacity and processes in the short term new information coming from an external source or old information recalled from long-term memory; and (3) long-term memory, which has enormous capacity and durability and stores information more permanently (Atkinson \& Shiffrin, 1968; Thornbury, 2006). It is usually necessary for information in working memory to be rehearsed for some time (silent mental repetition) so that it can move to long-term memory as a result of strengthening the memory trace. However, information should be frequently retrieved lest it decays and disappears (Thornbury, 2006). Thus, the key to storing material in long-term memory is rehearsal and retrieval. According to Calvert and Tart (1993), "songs present content in a form that may be easily stored, rehearsed, and retrieved from memory" (p. 246). While the content of a song involves the lyrics and the message of the lyrics, the form of a song involves the rhyme of the words, the repetition of a verse, the rhythm and the melody of the tune (Calvert \& Tart, 1993). This musical structure of songs provides a schematic organization which allows the retrieval of lyric information (Sloboda, 1989). Apart from having a repetitive structure, songs evoke strong emotions and present the language items in a meaningful context, which considerably facilitates their memorization both inside and outside the classroom, as emotions enhance memory processes (Jäncke, 2008) and meaningfully learned material has greater potential for retention in long-term memory (Ausubel, 1965).

According to Murphey (1990), songs are particularly beneficial to language acquisition because they trigger more effectively the din (i.e. the involuntary mental rehearsal of recently heard words, sounds and phrases), which according to Krashen's Din in the Head Hypothesis is "a result of stimulation of the Language Acquisition Device [or LAD]" (1983, p. 43) and "a sign that language acquisition is taking place" (2008, p. 349). Murphey (1990) argues that in contrast to the language din, the "Song stuck in my head" (SSIMH) phenomenon (i.e. the echoing in the mind of a previously heard song) can be triggered with considerably smaller amount of input time, does not necessitate understanding of the linguistic content and lasts for a longer period of time. Consequently, music and songs can play an "associative facilitating role" in engaging and stimulating the LAD (Murphey, 1990, p. 61). He further states that reading the lyrics while listening to songs can result in a stronger activation of the SSIMH (Murphey, 1990). 
A number of studies on second and foreign language learners have shown the positive effect of music and songs on the retention and recall of words, phrases and longer text (Medina, 1990; Salcedo, 2002; Legg 2009; Ludke, 2010; Salcedo 2010; Rukholm, 2011; Coyle \& Gómez Gracia, 2014). Notably, the study by Salcedo (2010) investigated the effect of utilizing songs on text recall and involuntary mental rehearsal (din) in Spanish language classrooms for English native-speaker students at a university in the United States. Results demonstrated that using songs led to a better text recall as compared to text passage. With regard to involuntary mental rehearsal, two thirds of the students in the "music group" reported experiencing the din as opposed to one third of students in the "text group" (Salcedo, 2010). A recent comprehensive research project by Tegge (2015) involving 568 teachers of 20 languages in 41 countries investigated "whether songs as they are frequently used in language teaching rather than as they potentially should be used" (p. 4) have a beneficial effect on lexical learning. Based on the findings from three separate studies exploring various ways songs can be used in second language teaching, the researcher concluded that "the way teachers currently tend to use songs in language classrooms around the world can benefit lexical learning, in particular the consolidation of already familiar vocabulary and the acquisition of deep word knowledge beyond a first form-meaning connection" (Tegge, 2015, p. 197). She further noted that "while certain structural characteristics of songs have the potential of rendering text (and the lexis therein) memorable, it is the way that songs tend to be exploited in the classroom that capitalizes on this mnemonic potential" (Tegge, 2015, p. ii).

\section{Music, Linguistic and Cultural Competence}

In addition to addressing multiple intelligences, providing a positive learning environment, increasing students' motivation and functioning as an effective memory aid, music and songs offer a realistic context for developing all the four language skills (i.e. listening, speaking, reading and writing) and can be integrated into pronunciation, vocabulary and grammar instruction while also offering a change to the classroom routine (Failoni, 1993; Lo \& Li, 1998; Abbott, 2002). As stated by Chuang (2016) lyrics in songs are "optimal language input because the input chunks provided are manageable for beginning learners, blending rhythm, stress, rhymes, intonation, vocabulary, and sentence patterns" (p. 28). According to Murphey's (1992) analysis, popular songs are generally short, use conversational language, contain repetitions and display a comparatively simple vocabulary associated with the level of 11-year-old native English speakers, which makes them particularly useful as entry-level materials, though they can also be adapted for advanced learners. 
It is particularly suitable to teach unknown words and idiomatic expressions with the use of songs as they provide meaningful examples presented in realistic contexts, which can make learning considerably easier compared to traditional methods of teaching vocabulary. In addition, collocations, figurative language and metaphors as well as colloquial language can be introduced through songs in a natural and convenient manner. Moreover, connected speech, pronunciation and intonation can be ideally practised with songs as their lyrics reflect the natural language with words presented at a slower pace than usual speech (Murphey, 1992; Ludke 2009). From the grammatical point of view, songs "provide a natural context for the most common structures such as verb tenses and prepositions" (Griffee, 1992, pp. 5-6). However, the main advantage of the incorporation of songs into the classroom is related specifically to listening, which is considered one of the most neglected skills (Paulston \& Bruder, 1976). Nunan (1999) describes listening as the "Cinderella skill" in second language teaching and learning due to its perceived minor importance compared to the other language skills. Nevertheless, listening is proven to play a more important role than other language skills in people's daily life as it is used twice as much as speaking, four times more than reading and five times more than writing (Rivers, 1981). What is more, several authors consider listening as the most important skill in learning a new language by virtue of its acting as base for the development of other skills (Lacorte \& Thurston-Griswold, 2001; Rost, 2013). Different sources of listening difficulty such as sound-letter relationship can be dealt with by using songs for practising rhythm pattern and connected speech (Rixon, 1986). Music can help the development of such essential skills as active listening and differentiation of sound patterns (Ludke, 2009). Another benefit of using songs in the classroom is that learners become exposed to a wide range of varieties of English. As stated by Harmer (1998), "One of the main reasons for getting students to listen to spoken English is to let them hear different varieties and accents - rather than just the voice of their teacher with its own idiosyncrasies" (p. 97).

Apart from developing students' linguistic competence, music and songs can also raise their cultural awareness. As stated by Jones (2008), "music is a faithful reflection of the culture it derives from" (p. 11). Music and songs of different genres contribute to the promotion of cultural diversity by conveying original styles, lexicons and feelings (Mõts, 2016). According to Shen (2009) "language and music are interwoven in songs to communicate cultural reality in a very unique way" (p. 88). By giving a better understanding of the language in its relevant cultural context, music and songs can enhance students' intercultural competence, which is one of the major goals of language teaching (Jolly, 1975; Karabinar \& Guler, 2013). 
In addition to numerous studies on the effects of music and songs on vocabulary learning mentioned earlier, several studies have shown that listening, pronunciation, speaking, grammar, reading and writing skills as well as cultural knowledge can be supported by using music and songs (Lowe, 1995; Fisher, 2001; Arévalo, 2010; Ludke; 2010; Setia et al. 2012; Kara \& Aksel, 2013; Lee \& Lin, 2015; Alisaari \& Heikkola, 2016). In particular, the study by Arévalo (2010) investigated the effectiveness of English songs "as a tool to foster listening skills as well as to engage students in cultural knowledge" (p. 127). The action research study involved adult EFL students at a university in Colombia. Based on the findings of the study, the researcher concluded that "songs are the most suitable type of authentic material to develop listening comprehension" (p. 130), which can also be utilized for practice at more advanced levels. The results also indicate that songs are effective in encouraging students to discuss cultural issues and social problems. In addition, the researcher reached the following conclusions that advocate the use of music and songs in the language classroom:

- The students feel motivated to participate in classes involving songs.

- It is considerably more attractive for the students to understand the language and the culture through learning with songs.

- Songs enable the students to become better aware of the correct pronunciation.

- Songs contain colloquial language with ample repetitions, which have a facilitative effect on language learning.

- Songs make language learning more interesting and effective by engaging the students in the interactive and reflective processes as they discover the content and meaning of the songs for themselves (Arévalo, 2010, pp. 130-131).

As the review of literature above suggests, many cogent reasons can be given for using music and songs in the ESL classroom. Yet, as stated by Murphey (1992), "songs alone [...] will not teach anyone how to use a language, no matter how great their memorability, how much fun it is to sing and listen to them, or how 'energizing' the change of pace might be" (p. 6). In other words, merely listening to or performing songs will hardly enable the students to acquire the ability to communicate in the target language. In order to improve the students' language skills, it is crucial that teachers utilize the songs through appropriate classroom activities. The subsequent section of the paper provides some practical suggestions for integrating music activities in language classrooms.

\section{Integrating Music and Songs in ELT}

Given the teacher's role in tapping the advantages of music and songs in the language classroom, this section presents certain practical guidelines for selecting music and songs as well as structuring classroom activities around them, which are followed by some creative music activities.

\section{Selecting Music and Songs}

There are plenty of songs available, especially online. But, not every song is suitable for teaching purposes. There are a number of factors that teachers should take into account when choosing a song for ESL classroom activities. 


\section{1) Purpose of the Song}

Above all, the song to be used should have instructional value. It is crucial to determine what students can learn from or practise with a song and select songs that are related to the theme, grammatical structures or vocabulary covered in the class. Simple songs with recurring grammar features are suitable for grammar activities, while more sophisticated songs that contain idioms and metaphors are useful for practising vocabulary. As far as listening activities are concerned, it is recommended to use songs with appropriate repetition, moderate tempo and simpler syntax. When there is a need to focus on pronunciation, songs with colloquial speech are ideal for practising reduction and linking. Songs that tell exciting stories can serve as topics for classroom discussions and written assignments (Abbott, 2002; Salcedo, 2002; González, 2007). Apart from vocal music, instrumental compositions can also be used for speaking and writing activities, whereby the teacher can prompt the students to express their feelings and associations in relation to particular melodies.

\section{2) The Age and Proficiency Level of the Students}

It goes without saying that the music and songs to be selected should correspond to the age and proficiency level of the students. For young learners, it is beneficial to use nursery or children's songs, which native-speaking infants are usually taught, because they are characterized by overall natural and rhythmic language with appropriate vocabulary and grammar as well as enjoyable phrase repetitions (Failoni, 1993; Zogota 2011). Similarly, songs produced especially for English language learners with controlled grammar and vocabulary can suit both young and adult beginners, though authentic songs of appropriate level of difficulty would hold greater appeal. In particular teenagers would definitely prefer learning English through popular songs, which can be used as an excellent opportunity to spark their interest in language learning. Although popular music can be helpful in learning the target language and its culture, several authors encourage the use of folk songs, which generally have superior prosodic quality, often tell a story and contain relatively simple melodies (Spicher \& Sweeney, 2007; Zogota, 2011). No matter what type of songs teachers select, it is crucial to make sure that they are neither too easy to challenge the learners nor too difficult lest they leave them feeling frustrated. Apart from the language used in the songs, the themes ought to be suitable for the students' age and interests (Abbott, 2002; González, 2007).

\section{3) Language Content and Quality of the Song}

It is vital to examine the language content and quality of the song by listening to it prior to presenting it to the learners. Songs can contain non-standard language, grammatically incorrect sentences, altered vocabulary, not well pronounced words and abbreviations. It is therefore important to choose, as far as possible, the songs written in standard language with lyrics identical in their written and recorded form and free from any confusing or inappropriate references. At the same time, the recording should be of good quality and the lyrics should be clear and easily distinguishable from the instrumental accompaniment (Lems; 2001; Abbott, 2002; Ashmore, 2011).

\section{4) Musical Preferences of the Students and the Teacher}

Several authors suggest that the students' musical preferences should be taken into consideration when choosing songs for music activities. Lems (2001) states it would motivate students to deal with 
newest popular songs or older hits, whose lyrics they might have heard but do not know very well. Likewise, Murphey (1992) recommends allowing students to put forward their choices as to the songs to be used as new material in the class so that they become actively engaged in the learning process. In addition to students' preferences, the musical taste of the teacher is also important. As stated by Lems (2001), "because teachers will show care and effort when presenting songs they are especially fond of, their favorites are also good". Similarly, Griffee (1992) emphasizes the importance of considering both the students' and the teacher's musical preferences: "It is not wise to use music that you do not like. It is also unwise to use music students do not like. The answer is to find common ground" (pp. 6-7). It is therefore advisable to ask the students to suggest song lyrics of their choice and to select the ones that have instructional values and are most popular with the students. Alternatively, teachers can make a list of different songs and let students choose, which will also involve them in their own learning.

\section{5) Format of the Song}

Music can be used either in audio or video format. While audio recordings are more readily available, music videos provide contextual information and can activate students' background knowledge, thereby enhancing comprehension. As stated by Marone (2018), teachers can explore "their multimodal features (music, lyrics, and moving images) and their multilayered meanings to increase students' linguistic and cultural competence" (p. 1). It is crucial, however, that teachers carefully select music videos to be used in the lessons paying special attention to their content and messages. As it is sometimes the case with popular music pieces, a song containing suitable lyrics can be debased due to its music video, which becomes inappropriate for the classroom use.

\section{6) Classroom Opportunities}

Teachers should also consider the availability of resources when they design music activities for the classroom. Such basic equipment as a computer with loudspeakers and a video projector will be needed to play songs or music videos in the classroom. In addition, music activities should be possibly conducted in large classrooms with appropriate acoustics. Lastly, care should be taken not to play music loudly so as not to cause inconvenience to other classes (Griffee 1992; Abbott, 2002).

\section{Structuring Music Activities}

Once teachers have selected the appropriate songs, they can design or adapt numerous classroom activities that can address all language skills. In order to make the experience of learning with music and songs as meaningful as possible for students, it is recommended to divide the music activities into three stages: pre-listening, while-listening and post-listening (Abbott, 2002; González, 2007; Lorenzutti, 2014; see Table 1). 
INTERNATIONAL JOURNAL OF ACADEMIC RESEARCH IN BUSINESS AND SOCIAL SCIENCES

Vol. 8, No. 12, Dec, 2018, E-ISSN: 2222-6990 @ 2018 HRMARS

Table 1: Three Stages of a Song

\begin{tabular}{|l|l|l|}
\hline Pre-listening stage & While-listening stage & Post-listening stage \\
\hline - warm-up questions & - recognizing theme-specific & - singing/chanting (for \\
- presentation of key & words or grammatical forms & fluency and pronunciation) \\
vocabulary, phrases or & (e.g. colors, animals/tenses) & - re-tell the story in the song \\
grammar structures & $\begin{array}{l}\text { - ordering words, lines or } \\
\text { - prediction activities }\end{array}$ & $\begin{array}{l}\text { - discuss the message of the } \\
\text { song }\end{array}$ \\
$\begin{array}{l}\text { (song title, content and } \\
\text { theme, singer) }\end{array}$ & $\begin{array}{l}\text { - listening for detail (gap-fill, } \\
\text { true/false, short answers, spot- } \\
\text { the-error) } \\
\text { - listening for gist (topic of the } \\
\text { song) }\end{array}$ & $\begin{array}{l}\text { - read an article related to } \\
\text { the topic of the song }\end{array}$ \\
& - matching (e.g. definitions) & \\
\hline
\end{tabular}

\section{1) Pre-listening Stage}

The purpose of the pre-listening stage is activating the students' background knowledge as well as generating their interest in the song. This stage can begin with warm-up questions, presentation of useful vocabulary and grammar structures or prediction activities. An example of prediction activities is when the teacher shows a picture or plays the introduction to the song and asks students to predict the title, content or theme of the song.

\section{2) While-listening Stage}

In the second stage, the students are required to listen to the song and to complete a certain task. For instance, the teacher could ask the students to underline specific words, to rearrange words or lines, to fill in gaps, to spot and correct mistakes or to match phrases with definitions. It is important to bear in mind that the song should be played at least two or three times to enable students to complete the task.

\section{3) Post-listening Stage}

In the post-listening stage, students can engage in speaking, writing or reading activities. By way of example, they can practice pronunciation and vocabulary by singing or chanting the song lyrics as a class or in groups. Besides, the students might sum up the action of the song or its main theme, discuss the message of the song or read a text related to the topic of the song.

\section{Creative Music Activities}

Apart from the activities mentioned above, teachers can use music in the classroom in various ways that go beyond listening to music and exploiting the song lyrics. Below are some student-centered music activities that can stimulate students' creativity, while also developing their language skills.

Free-write/free-draw to the music: The teacher can play different types of music and ask the students to write or draw how they feel about them. Every student can also make up their own stories for the music piece (Lems, 2001; Budden, 2008). 
Writing alternative verses of lyrics: Students can be encouraged to write their own lyrics, keeping the original mood or style. Students can do it in groups or individually, whereby each group or student will be responsible for writing a new part of the lyrics. In this way, the alternative lyrics of the entire song can be prepared and presented in the class (Shen, 2009; Simpson, 2015).

Planning (and filming) a music video: Groups of students can plan a music video for the song, focusing on the characters, the location and the storyline. After each group has explained the specific details of its plan for the music video in the class, the students can choose the one based on which the actual filming can be done (Simpson, 2015).

Preparing a lyric video: Students can prepare song lyric visualization videos by using song lyrics and relevant images. By doing this project, the students will not only be challenged to show their creativity and interpretive skills but they will also need to demonstrate that they clearly understand the vocabulary in the song so that they can pick up befitting images based on their understanding of the song (Lems, 2016).

Presenting on a musician or music genre: Students can be asked to make a presentation on a chosen musician or music style. In this project students are given the freedom to organize their entire project, including research on the topic of their interest and the presentation of their findings. As a result, the students can develop their academic skills, practice their oral and organizational skills (Lems, 2018).

As a matter of fact, the ideas discussed above only scrape the surface, considering the large number of creative ways that can be found for the adaptation of music and songs to the language classroom. In addition to pedagogical resource books (e.g., Griffee, 1992; Murphey, 1992; Paterson \& Willis, 2008; Arnold \& Herrick, 2017) and articles on the use of music and songs in ESL/EFL classrooms (e.g., Failoni, 1993; Lems, 2001, 2016, 2018; Abbott, 2002; Budden, 2008; Lorenzutti, 2014; Simpson, 2015), there are several websites (e.g., tefltunes.com, tuneintoenglish.com) containing ready-made songbased lesson plans and classroom activities for various proficiency levels, which ESL teachers can adapt to fit the needs of their students.

\section{Conclusion}

Nowadays, the role of a teacher is not only educating but also motivating students who regard traditional ways of learning as dull and boring. Therefore, language teachers are supposed to show creativity and enthusiasm as well as openness to new ideas and challenges, while also keeping a balance between serious learning and amusement. Music and songs provide teachers with a rich and authentic resource that they can utilize to promote student engagement in ESL classrooms and to make a satisfactory connection between entertainment and learning. As the review of recent research and literature suggests, the effective use of music and songs in language teaching has the potential to address multiple intelligences, reduce anxiety, increase motivation, facilitate memory retention and establish an affectively conducive learning environment. In addition to making lessons 
more interesting, music and songs can be used to enhance the learning of almost every aspect of the target language, to develop cultural awareness and to foster students' creativity.

It is hoped that a larger number of ESL teachers will deem music and songs a valuable educational tool which they can use to engage their students both affectively and cognitively as well as to promote effective and enjoyable language teaching and learning. For a successful implementation it is vital that teachers select appropriate music and songs that are related to lesson objectives and then carefully design or adapt classroom activities that will help to achieve them.

\section{References}

Abbott, M. (2002). Using Music to Promote L2 Learning among Adult Learners. TESOL Journal 11 (1): 10-17.

Alisaari, J., \& Heikkola, L. M. (2016). Increasing fluency in L2 writing with singing. Studies in Second Language Learning and Teaching, 6(2), 271-292.

Arévalo, E. A. R. (2010). The use of songs as a tool to work on listening and cultur listening and culture in EFL classes classes. Cuadernos de Lingüística Hispánica, (15), 121-138.

Arnold, J., \& Brown, H. D. (1999). A map of the terrain. In J. Arnold (Ed). Affect in Language Learning (pp. 1-24). Cambridge: Cambridge University Press.

Arnold, J. L., \& Herrick, E. (2017). New Ways in Teaching with Music. Alexandria, VA: TESOL Press.

Ashmore, M. (2011). Choosing Tunes. English Teaching Professional, Issue 72, 22.

Atkinson, R. C., \& Shiffrin, R. M. (1968). Chapter: Human memory: A proposed system and its control processes. In Spence, K. W., \& Spence, J. T. The Psychology of Learning and Motivation (Volume 2) (pp. 89-195). New York: Academic Press.

Ausubel, D. (1965). Introduction to part one. In R. Anderson \& D. Ausubel (Eds.), Readings in the Psychology of Cognition (pp. 3-17). New York: Hold, Rinehart \& Winston.

Besson, M., Schön, D., Moreno, S., Santos, A., \& Magne, C. (2007). Influence of musical expertise and musical training on pitch processing in music and language. Restorative neurology and neuroscience, 25(3-4), 399-410.

Brandt, A. K., Slevc, R., \& Gebrian, M. (2012). Music and early language acquisition. Frontiers in psychology, 3, 327.

Brown, P. (1998). The sound of music. Met, London, 7 (3), 67-68.

Budden, J. (2008). Using music and songs. British Council. Retrieved 17.05 .2018 from https://www.teachingenglish.org.uk/article/using-music-songs

Calvert, S. L., \& Tart, M. (1993). Song versus verbal forms for very-long-term, long-term, and shortterm verbatim recall. Journal of Applied Developmental Psychology, 14(2), 245-260.

Campbell, L., Campbell, B., \& Dickinson, D. (1996). Teaching and learning through multiple intelligences. New York: Basic Books.

Cervellin, G., \& Lippi, G. (2011). From music-beat to heart-beat: a journey in the complex interactions between music, brain and heart. European journal of internal medicine, 22(4), 371-374.

Chanda, M. L., \& Levitin, D. J. (2013). The neurochemistry of music. Trends in cognitive sciences, 17(4), 179-193. 
INTERNATIONAL JOURNAL OF ACADEMIC RESEARCH IN BUSINESS AND SOCIAL SCIENCES

Vol. 8, No. 12, Dec, 2018, E-ISSN: 2222-6990 @ 2018 HRMARS

Chuang, L. L. (2016). Accessing the Workings of the Mind: From Input to Intake. Oxford: Chartridge Books Oxford.

Coyle, Y., \& Gómez Gracia, R. (2014). Using songs to enhance L2 vocabulary acquisition in preschool children. ELT Journal, 68 (3), 276-285.

Crookes, G. \& Schmidt, R. (1991). Motivation: Reopening the research agenda, Language Learning, 41 (4), 469-512.

Davis, K., Christodoulou, J., Seider, S., \& Gardner, H. (2011). The theory of multiple intelligences. In R.J. Sternberg \& S.B. Kaufman (Eds.), Cambridge Handbook of Intelligence (pp. 485-503). Cambridge, UK; New York: Cambridge University Press. Retrieved 17.05.2018 from https://ssrn.com/abstract=2982593

Deci, E. (1995). Why we do what we do: The dynamics of personal autonomy. New York: Putnam.

Drazen, D. L., \& Woods, S. C. (2003). Peripheral signals in the control of satiety and hunger. Current Opinion in Clinical Nutrition \& Metabolic Care, 6(6), 621-629.

Džanić, N. D., \& Pejić, A. (2016). The Effect of Using Songs On Young Learners and Their Motivation for Learning English. NETSOL 1 (2), 40-54.

Engh, D. (2013). Effective Use of Music in Language-Learning: A Needs Analysis. Humanising Language Teaching 15 (5).

Failoni, J. W. (1993). Music as Means To Enhance Cultural Awareness and Literacy in the Foreign Language Classroom. Mid-Atlantic Journal of Foreign Language Pedagogy, 1, 97-108.

Fisher, D. (2001). Early language learning with and without music. Reading Horizons, 42(1), 39-49.

Gardner, H. (1983). Frames of Mind: The Theory of Multiple Intelligences. New York: Basic Books.

Gardner, H. (2011). Frames of Mind: The Theory of Multiple Intelligences. New York: Basic Books.

Gardner, H. (2013). Howard Gardner: 'Multiple intelligences' are not 'learning styles'. The Washington Post, $16 . \quad$ https://www.washingtonpost.com/news/answersheet/wp/2013/10/16/howard-gardner-multiple-intelligences-are-not-learningstyles/?utm_term $=.95$ cce7fof698

Gardner, R.C., \& Lambert, W. (1972). Attitudes and motivation in second language learning. Rowley: Newbury House.

González, J. M. (2007). The Power of Songs: Why and How Does Music Improve Language Learning? In C. P. Pascaul (Ed.), Revisiting language learning resources, 323-346. Newcastle, UK: Cambridge Scholars Publishing.

Green, J. M. (1993). Student attitudes toward communicative and non-communicative activities: Do enjoyment and effectiveness go together? The Modern Language Journal, 77(i), 1-10.

Griffee, D. T. (1992). Songs in Action. London: Prentice Hall International.

Harmat, L., Takács, J., \& Bodizs, R. (2008). Music improves sleep quality in students. Journal of advanced nursing, 62(3), 327-335.

Harmer, J. (1998). How to Teach English. Edinburgh: Addison Wesley Longman.

Jackson, M. F., \& Joyce, D. M. (2003). The Role of Music in Classroom Management. New York: New York University.

Jäncke, L. (2008). Music, memory and emotion. Journal of biology, 7(6), 21.

Jäncke, L. (2012). The relationship between music and language. Frontiers in psychology, 3, 123. 
Jolly, Y. S. (1975). The Use of Songs in Teaching Foreign Languages. The Modern Language Journal 59, 1/2, 11-14.

Jones, R. (2008). Echoing Their Lives: Teaching Russian Language and Culture through the Music of Vladimir S. Vysotsky (Doctoral Dissertation, University of Texas at Austin).

Kara, Z. E., \& Aksel, A. S. (2013). The effectiveness of music in grammar teaching on the motivation and success of the students at preparatory school at Uludağ University. Procedia-Social and Behavioral Sciences, 106, 2739-2745.

Karabinar, S., \& Guler, C. Y. (2013). A Review of Intercultural Competence from Language Teachers' Perspective. Procedia-Social and Behavioral Sciences, 70, 1316-1328.

Karageorghis, C. I., Mouzourides, D. A., Priest, D. L., Sasso, T. A., Morrish, D. J., \& Walley, C. L. (2009). Psychophysical and ergogenic effects of synchronous music during treadmill walking. Journal of sport and exercise psychology, 31(1), 18-36.

Kerekes, E. (2015). Using songs and lyrics in out-of-class learning. In D. Nunan \& J. Richards (Eds.), Language learning beyond the classroom (pp. 33-42). New York: Routledge.

Krashen, S. (1982). Principles and Practice in Second Language Acquisition. Oxford: Pergamon Press.

Krashen, S. (1983). The din in the head, input, and the language acquisition device. Foreign Language Annals, 16 (1), 41-44.

Krashen, S. (2008). Letter to the editor: The Din in the Head hypothesis: A response to de Bot (2008). Modern Language Journal. 92 (3), 349.

Lacorte, M., \& Thurston-Griswold, H. (2001). Music in the foreign language classroom: Developing linguistic and cultural proficiency. NECTFL Review, 49(40), 49-53.

Lake, R. (2002). Enhancing acquisition through music. The Journal of the Imagination in Language Learning, 7, 98-107.

Lee, L., \& Lin, S. C. (2015). The impact of music activities on foreign language, English learning for young children. Journal of the European Teacher Education Network, 10, 13-23.

Legg, R. 2009. Using music to accelerate language learning: An experimental study. Research in Education 82, 1-12.

Lems, K. (2001). Using music in the adult ESL classroom. ERIC Digest, National Clearinghouse for ESL Literacy Education.

Lems, K. (2016). Learning English through Music in the Digital Age. TESOL Video News. Alexandria, VA: Teachers of English to Speakers of Other Languages.

Lems, K. (2018). New Ideas for Teaching English Using Songs and Music. English Teaching Forum 56(1), 14-21.

Lo, R., \& Li, H. (1998). Songs enhance learner involvement. English Teaching Forum, 20, 44-45.

Lorenzutti, N. (2014). Beyond the Gap Fill: Dynamic Activities for Song in the EFL Classroom. English Teaching Forum 52 (1), 14-21.

Lowe, A. S. (1995). The Effect of the Incorporation of music learning into the second language classroom on the mutual reinforcement of music and language (Doctoral Dissertation, University of Illinois, Urbana-Champaign).

Lowe, M. (2007). Language and Music: The Parallels between Learning/Teaching Language and Learning/Teaching Music. Modern English Teacher 16(3), 5-11. 
INTERNATIONAL JOURNAL OF ACADEMIC RESEARCH IN BUSINESS AND SOCIAL SCIENCES

Vol. 8, No. 12, Dec, 2018, E-ISSN: 2222-6990 @ 2018 HRMARS

Ludke, K. M. (2009). Teaching Foreign Languages through Songs. Edinburgh: The University of Edinburgh.

Ludke, K. M. (2010). Songs and Singing in Foreign Language Learning. (Doctoral Dissertation, University of Edinburgh).

Marone, V. (2018). Teaching English through Music Videos. The TESOL Encyclopedia of English Language Teaching, 1-7.

Medina, S. L. (1990). The effects of music upon second language vocabulary acquisition. Paper presented at the Annual Meeting of the Teachers of English to Speakers of Other Languages (San Francisco, CA).

Medina, S. L. (2002). Using music to enhance second language acquisition: From theory to practice. In J. Lalas \& S. Lee (Eds.), Language literacy, and academic development for English language learners (pp. N/A). NY: Pearson Educational Publishing.

Metaxa, X. T. (2013). The effect of authentic songs on vocabulary acquisition in the English foreign language classroom (Doctoral Dissertation, Saint Louis University).

Mora, C. F. (2000). Foreign language acquisition and melody singing. ELT journal, 54(2), 146-152.

Mõts, M. (2016). The use of pop songs in the English language teaching: an analysis of the textbooks" Key English 7" and" English in mind 2" and the creation of additional materials to the textbooks (MA Thesis, University of Tartu).

Murphey, T. (1990). The song stuck in my head phenomenon: a melodic DIN in the LAD? System 18, 53-64.

Murphey, T. (1992). Music and Song. Oxford: Oxford University Press.

Nunan, D. (1999). Second language teaching and learning. Boston: Heinle and Heinle.

Paterson, A., \& Willis, J. L. (2008). English through Music. Oxford: Oxford University Press.

Paulston, C. B. \& Bruder, M. N. (1976). Teaching English as a Second Language. Techniques and Procedures. Boston: Little Brown \& Company.

Peacock, M. (1997). The effect of authentic materials on the motivation of EFL learners. ELT journal, 51(2), 144-156.

Putkinen, V., Tervaniemi, M., Saarikivi, K., de Vent, N., \& Huotilainen, M. (2014). Investigating the effects of musical training on functional brain development with a novel Melodic MMN paradigm. Neurobiology of Learning and Memory, 110, 8-15. doi: 10.1016/j.nlm.2014.01.007

Richards, J. (1969). Songs in language learning. TESOL Quarterly, 3(2), 161-174.

Ritter, S. M., \& Ferguson, S. (2017). Happy creativity: Listening to happy music facilitates divergent thinking. PloS one, 12(9), e0182210.

https://doi.org/10.1371/journal.pone.0182210

Rivers, W. (1981). Teaching foreign-language skills. Chicago: Chicago University Press.

Rixon, S. (1986). Developing Listening Skills. London. Macmillan Publishers Ltd.

Rost, M. (2013). Teaching and Researching: Listening. Oxon: Routledge.

Rukholm, V.N. (2011). Facilitating Lexical Acquisition in Beginner Learners of Italian through Popular Song. Doctoral Thesis, University of Toronto.

Salcedo, C. S. (2002). The effects of songs in the foreign language classroom on text recall and involuntary mental rehearsal (Doctoral Dissertations, Louisiana State University). 
INTERNATIONAL JOURNAL OF ACADEMIC RESEARCH IN BUSINESS AND SOCIAL SCIENCES

Vol. 8, No. 12, Dec, 2018, E-ISSN: 2222-6990 C 2018 HRMARS

Salcedo, C. S. (2010). The Effects of Songs in the Foreign Language Classroom on Text Recall, Delayed Text Recall and Involuntary Mental Rehearsal. Journal of College Teaching \& Learning, 7(6), 1930.

Schäfer, T., Sedlmeier, P., Städtler, C., \& Huron, D. (2013). The psychological functions of music listening. Frontiers in psychology, 4, 511.

Schön, D., Boyer, M., Moreno, S., Besson, M., Peretz, I., \& Kolinsky, R. (2008). Songs as an aid for language acquisition. Cognition, 106(2), 975-983.

Setia, R., Rahim, R. A., Nair, G. K. S., Mohd Adam, A. F. B., Husin, N., Sabapathy, E., Mohamad, R., Mat So'od, S. M., Md Yusoff, N. I., Mohd Razlan, R., Abd Jalil, N. A., Kassim, R. M., \& Abu Seman, N. (2012). English songs as means of aiding students' proficiency development. Asian Social Science, 8(7), 270-274

Shen, C. (2009). Using English Songs: An Enjoyable and Effective Approach to ELT. English language teaching, 2(1), 88-94.

Simpson, A. J. (2015). How to use songs in the English language classroom. British Council. Retrieved 17.05.2018 from https://www.britishcouncil.org/voices-magazine/how-use-songs-englishlanguage-classroom

Sloboda, J. A. (1989). The musical mind: The cognitive psychology of music. Oxford: Oxford University Press.

Snyder, K. L., Snaterse, M., \& Donelan, J. M. (2012). Running perturbations reveal general strategies for step frequency selection. Journal of Applied Physiology, 112(8), 1239-1247.

Spicher, L. \& Sweeney, F. (2007). Folk Music in the L2 Classroom: Development of Native-Like Pronunciation through Prosodic Engagement Strategies. Connections, 1, 35- 48.

Stevick, E. (1980). Teaching Languages. A Way and Ways. Rowley, MA: Newbury House.

Tegge, F. A. G. (2015). Investigating song-based language teaching and its effect on lexical learning. (Doctoral Dissertation, Victoria University of Wellington).

Thornbury, S. (2006). An AZ of ELT. Oxford: Macmillan Education.

Trappe, H. J. (2009). Musik und Gesundheit. Welche Musik hilft welchem Patienten - welche eher nicht? DMW-Deutsche medizinische Wochenschrift (1946), 134(51-52), 2601-2606.

Zogota, N. (2011). Using songs, music and lyrics in English teaching: A reference book. Rogovka: Nautreni Secondary School. 